\title{
Differences between men and women with a dismissing attachment style regarding their attitudes and behaviour in romantic relationships
}

\author{
Adelaida Monteoliva, J. Miguel A. García-Martínez, Antonia Calvo-Salguero, \\ and Maria-del-Carmen Aguilar-Luzón
}

Department of Social Psychology, Granada University, Granada, Spain

\begin{abstract}
$R$ esearch to date has revealed that the association between gender, attachment and the quality and functioning of intimate relationships is complex. This study examined the relationship between gender and attachment styles in attitudes to communication with one's partner and in the number of past relationships in a sample of 746 Spanish undergraduates. The Relationship Questionnaire was administered to them to determine the adult attachment style. The results revealed the existence of differences according to the adult attachment style and gender with regard to the two measured variables, and a significant effect of the interaction between gender and attachment. Dismissing men reported the highest average scores in the number of past relationships, with significant differences appearing when they were compared with secure and preoccupied men. However, dismissing women did not differ from the rest of the women with other attachment styles. When men and women with the same attachment styles were compared in this variable, the only significant differences were found between dismissing men and women (with the latter reporting fewer partners). In the case of attitudes to expressing feelings to one's partner, dismissing men reported the most negative attitudes, compared with secure and preoccupied men. Dismissing women, unlike the men, did not differ in their attitudes either from preoccupied or fearful women. Moreover, clear differences were shown between dismissing men and women in these attitudes (more negative in the case of men).
\end{abstract}

Keywords: Adult attachment; Gender differences; Attitudes; Intimate relationships.

\begin{abstract}
J usqu'à ce jour, la recherche a révélé que l'association entre le genre, l'attachement et la qualité et le fonctionnement des relations intimes est complexe. Cette étude examinait la relation entre le genre et le style d'attachement en lien avec les attitudes envers la communication avec son conjoint et le nombre de relations conjugales passées. L'étude fut réalisée auprès d'un échantillon de 746 étudiants espagnols de premier cycle universitaire. Le Questionnaire sur les relations a été administré aux participants afin de déterminer leur style d'attachement adulte. Les résultats ont révélé des différences selon le style d'attachement et le genre relativement aux deux variables examinées, ainsi qu'un effet d'interaction significatif entre le style d'attachement et le genre. Les hommes ayant un attachement détaché ont rapporté les scores moyens les plus élevés pour le nombre de relations passées, lesquels sont significativement différents des scores obtenus par les hommes ayant un attachement sécurisant ou préoccupé. Cependant, les femmes détachées ne se sont pas avérées différentes des femmes ayant un autre style d'attachement. La comparaison des hommes et des femmes ayant le même style d'attachement, par rapport au nombre de relations passées, a révélé des différences significatives seulement entre les hommes et les femmes détachés (ces dernières ont rapporté le moins grand nombre de partenaires). Concernant les attitudes envers l'expression des sentiments à son conjoint, les hommes détachés ont rapporté les attitudes les plus négatives, comparativement aux hommes sécurisés ou préoccupés. Les femmes détachées, contrairement aux hommes, ne présentaient pas de différence dans leurs attitudes comparativement aux femmes préoccupées ou craintives. De plus, des différences claires ont été obtenues entre les hommes et les femmes détachés relativement à ces attitudes (lesquelles sont plus négatives chez les hommes).
\end{abstract}

Correspondence should be addressed to Adelaida Monteoliva, Department of Social Psychology, Faculty of Psychology, Granada University, 18071-Granada, Spain. (E-mail: amonteol@ugr.es).

(C) 2012 International Union of Psychological Science

http://www.psypress.com/ijp

http://dx.doi.org/10.1080/00207594.2011.634007 
asta ahora, la investigación ha revelado que la asociación entre el género, el apego y la calidad y el
funcionamiento de las relaciones íntimas es compleja. Este estudio examinó la relación entre el género y los
estilos de apego en las actitudes hacia la comunicación con la pareja y en el número de relaciones anteriores en
una muestra de 746 estudiantes universitarios españoles, a quienes se les administró el Relationship
Questionnaire [Cuestionario de Relaciones] para determinar el estilo de apego adulto que presentaban.
Los resultados revelaron la existencia de diferencias según el estilo de apego adulto y el género en relación a
las dos variables evaluadas, y un efecto significativo de la interacción entre el género y el apego. Los hombres con
apego rechazante mostraron el mayor promedio de relaciones anteriores, haciéndose evidentes las diferencias
significativas cuando se los comparaba con los hombres con apego seguro y preocupado o temeroso.
Sin embargo, las mujeres con apego rechazante no se diferenciaron del resto de las mujeres con otros estilos de
apego. Cuando se compararon los hombres y mujeres con el mismo estilo de apego en esta variable, las
diferencias significativas sólo se manifestaron entre los hombres y mujeres con apego rechazante (las mujeres
informando haber tenido menos parejas). En el caso de las actitudes hacia la expresión de sentimientos a la
pareja, los hombres con apego rechazante informaron las actitudes más negativas en comparación con los
hombres con apego seguro y apego preocupado o temeroso. Las mujeres con apego rechazante, a diferencia de
los hombres, no difirieron en sus actitudes en comparación con las mujeres con apego preocupado o temeroso.
Además, se mostraron diferencias claras en estas actitudes entre hombres y mujeres con apego rechazante
(más negativas en el caso de los hombres).

Bowlby's attachment theory (Bowlby, 1969/1982) refers to the first affectional bonds established between the child and his or her primary caregiver, as well as the consequences of this bond on their subsequent socioemotional development. The main supposition of this theory is that the attachment relations that the infant establishes through the first interactions with his or her primary caregiver give rise to the formation of typical mental schemas or representations of relationships. These cognitive schemas, or internal working models, are consolidated during infancy and early childhood and over time they are converted into generalized beliefs and expectations regarding self, significant others, and social relationships in general, being influential the rest of the individual's life.

Hazan and Shaver (1987) developed a brief instrument to measure attachment patterns in adults, the Attachment Questionnaire (AQ). The AQ identified three styles in adults, one secure and two insecure (avoidant and anxiousambivalent). Subsequently, Bartholomew (1990; Bartholomew \& Horowitz, 1991) extended the adult attachment styles to four, which originated from the cognitive models of self and others in relationships. The combination of the models and their corresponding valences (positive or negative) would lead to four attachment styles: secure (with a positive model of themselves and a positive model of others), avoidant-dismissing (with a positive model of themselves and a negative model of others), preoccupied (with a negative model of themselves and a positive model of others) and avoidant-fearful (with both models being negative), each reflecting individual differences in self-concept and interpersonal functioning.

\section{ADULT ATTACHMENT AND ROMANTIC RELATIONSHIP}

Since attachment theory appeared, the majority of studies have been aimed at exploring the implications of attachment in different types of adult relationship, principally in romantic relationships. Ample research has indicated that the attachment styles are related to the way in which the person feels, thinks and behaves in their romantic relationships and affect the quality and functioning of these relationships (Simpson, Collins, Tran, \& Haydon, 2007).

In particular, security in attachment seems to be related to more positive romantic relationships, contrary to what happens in an insecure attachment. Thus, secure persons have relationships that are characterized by intimacy, satisfaction, trust, and stability, unlike persons with avoidant attachment, who tend to have relationships marked by low levels of intimacy, commitment, trust, and satisfaction. People with preoccupied attachment (anxious-ambivalent) state that their relationships are characterized by conflict, jealousy, and negative emotional experiences (Collins \& Read, 1990; Monteoliva \& García-Martínez, 2005; Yárnoz, Alonso-Arbiol, Plazaola, \& Sainz de Murieta, 2001). Likewise, insecurity in attachment is associated with shorter partner relationships (especially avoidant attachment), a higher probability of divorce, and a higher number of break-ups 
(Hazan \& Shaver, 1987; Kirkpatrick \& Davis, 1994).

Different models of interpersonal communication according to adult attachment style have also been found (see Feeney, 1999a, for a review). Within this process, a widely studied variable has been self-disclosure, defined as the communication of personally important information, thoughts, and feelings to other persons (Perlman \& Fehr, 1987). This aspect has often been taken as another intimacy indicator in interpersonal relationships (Reis \& Patrick, 1996).

In general, compared with avoidant (fearful and dismissing) individuals, secure and anxious/ ambivalent (or preoccupied) persons have a greater tendency to disclose varied personal information and they prefer persons who tend to disclose information in their relationships (Monteoliva \& García-Martínez, 2005; Pistole, 1993).

As note above, there is solid evidence of a relationship between security-insecurity in attachment and the satisfaction and functioning of intimate relationships. However, studies have revealed that certain individual variables, such as gender or gender role, have a moderating effect on these relationships. Nevertheless, no clear conclusions have been found to date, which makes this a current topic subject to debate (see Mikulincer \& Shaver, 2007).

\section{GENDER AND ROMANTIC RELATIONSHIP}

Research into whether men and women differ in their attitudes and behaviour in romantic relationships has found some differences. So, for example, women feel more committed and get more involved in their relationships than men, they make greater efforts to maintain these relationships, and they show a higher degree of satisfaction with their relationships (Canary \& Wahba, 2006), while men disclose that they have had more partner relationships throughout their life and show more permissive and instrumental sexual attitudes (Hendrick \& Hendrick, 1995). In other areas, such as communication in relationships, studies have highlighted that women disclose more personal information than men, particularly in intimate relationships (see Reis \& Patrick, 1996, for reviews). The disclosure of intimate information, and particularly about feelings, seems to be more typically feminine behaviour, while men disclose more information about their personal achievements (Murstein \& Adler, 1995). In Spain, research in the field of romantic and sexual behaviour has also found gender differences. Studies have highlighted that men have a higher number of sexual partners than women, whose partnerships are more stable (Teva, Bermúdez, \& Buela-Casal, 2009) and that both the length of the relationship and the openness in communication predict romantic and sexual satisfaction in women, but not in men (Yela, 2000). Furthermore, although women are more permissive than in previous times, in line with the changes that have come about in today's society, they still perceive romantic relationships to be connected with sexual relationships to a greater extent than men, which leads to a greater probability that they will reject a sexual encounter without being in love (Instituto de la Juventud, 2004).

These results have been interpreted from the socialization processes received according to gender, given that, in our society, having a large number of partner relationships or sexual relationships is something that men may feel proud of and that women may feel ashamed of, with feminine promiscuity being frowned upon not just among men, but also among women themselves (Yela, 2000).

\section{ADULT ATTACHMENT, GENDER AND ROMANTIC RELATIONSHIP}

With regard to adult attachment, there is also empirical evidence that men and women with the same attachment styles have different perceptions of their romantic relationships (Collins \& Read, 1990; Kirkpatrick \& Davis, 1994; Pietromonaco \& Carnelley, 1994). So, for example, differences have been found between men and womenin both avoidant (particularly dismissing) and anxious/ ambivalent (or preoccupied) styles in aspects such as sexual relations (Birnbaum, Reis, Mikulincer, Gillath, \& Orpaz, 2006) and in regulating affection (Powers, Pietromonaco, Gunlicks, \& Sayer, 2006). Among the anxious/ambivalent group, men revealed more information than women, and among the avoidant group, men were perceived by their partners to be less affectionate and less communicative.

All these results would highlight the influence of gender socialization on romantic relationships. As the social role theory (Eagly, 1987) proposes, women are socialized to be communal and men to be agentic. These differences generate gender role schemas that can affect our interactions as adults. As Wood and Eagly (2002) have pointed out, the way we behave in our interpersonal relationships, and our perception and interpretation of others' 
behaviour, may vary according to that differential socialization. To this effect, the gender differences found in the evaluation of romantic relationships and their functioning could be partially explained by the style of socialization received. Some studies revealed that men seem to be more dismissing than women and women seem to be more preoccupied than men (Birnbaum et al., 2006; Feeney, 1999b). All these results are consistent with previous findings showing that gender differences in dismissing romantic attachment were evident in most cultures, with men generally reporting higher levels of dismissing attachment than women (Schmitt et al., 2003).

Therefore, research to date has revealed that the association between gender, attachment, and the quality and functioning of intimate relationships is complex. As several authors have noted, these connections would need to be assessed in greater detail on both an individual and a partner level (Mikulincer \& Shaver, 2007; Powers et al., 2006). And this is where our research comes in.

\section{PURPOSE OF THE STUDY}

The main purpose of this study was to examine the relationship between gender and attachment styles in the context of romantic relationships. We expect to find a significant effect of the interaction of both variables (attachment-gender) on attitudes and behaviour in romantic relationships, seeing that, in certain aspects of a relationship, gender may have a marked moderating effect, given that social pressure or socializing burden may be stronger than the effect of the attachment style. We believe that, although gender and attachment style have independent influences on attitudes and behaviour in romantic relationships, these relations could change when we take both factors together. In order to put this hypothesis to the test, we selected aspects of relationships that display a different socializing burden: behaviour related to the degree of stability, as would be the case of having maintained greater or fewer partner relationships in the past; and an aspect related to the degree of intimacy, as would be the attitudes to expressing feelings to one's partner. Furthermore, and bearing in mind that different studies have revealed differences between avoidant men and women in some aspects of romantic relationships (particularly in the dismissing attachment style), while there are hardly any apparent differences between men and women with other attachment styles (Mikulincer \& Shaver, 2007), we are going to focus our predictions on the dismissing attachment style, as we also believe that it is the style that best represents the masculine gender role stereotype and that least represents the feminine stereotype.

Several contributions are made with this study; firstly, and taking on the proposal made by different authors, we aim to provide new data that will clarify the interaction between attachment style and biological sex in terms of analyzing the functioning of romantic relationships. Secondly, we are working with a behaviour that has a strong socializing burden, and that has not been studied before to analyze this moderating effect, such as the number of past partners. We are also interested in verifying whether this effect is produced in other aspects of relationships in which the socializing burden is lighter, as is the case with attitudes to self-disclosure. Thirdly, we have focused on the dismissing attachment style in order to see whether we can confirm the data found in some studies indicating how dismissing women behave differently in relationships compared with dismissing men. Lastly, transcultural research on attachment suggests that this variable seems to be determined not only by universal factors but also by contextual or specific factors of a particular culture (van IJzendoorn \& Sagi, 1999). On this basis, the results of this study could be useful in verifying whether the relations found in samples from other cultures between attachment, gender, and romantic relationship can be confirmed in Spanish samples, with the purpose of contributing data that, added to the other crosscultural studies, will allow the universal validity of the attachment theory to be put to the test.

\section{HYPOTHESES OF THE STUDY}

In general terms, we expect to find a significant effect of the interaction between gender and attachment in the case of the dismissing avoidant style, given that this attachment style is consistent with the typically masculine gender role, but inconsistent with the typically feminine gender role. The consequences of being dismissing in one's attachment will therefore differ for men and women. All this leads us to formulate more specifically the following hypotheses:

\section{Hypothesis 1: Number of past partners}

- H.1.1: Men with dismissing attachment style will report a higher number of past relationships than secure and preoccupied men.

- H.1.2: Women with dismissing attachment style will not significantly differ from all the 
other women with other styles in the number of partner relationships.

- H.1.3: When men and women with the same attachment style are compared, we expect the only differences in the number of past partners to arise in the case of the dismissing attachment style.

\section{Hypothesis 2: Attitudes to expressing feelings to one's partner}

- H.2.1: Men with dismissing attachment style will report more negative attitudes to the disclosure of personal information than secure and preoccupied men.

- H.2.2: Women with dismissing attachment style will not significantly differ from all the other women with other styles in their attitudes to the disclosure of personal information.

- H.2.3: When men and women with the same attachment style are compared, we expect the only differences in attitudes to arise in the case of the dismissing attachment style.

\section{METHOD}

\section{Participants and procedure}

The sample for this study was made up of 746 Spanish students of Granada University from eight different centers (university schools and faculties), who were in a partner relationship at the time of the research. The average length of the relationships was 32.44 months. Of the total number of participants, 201 were men and 545 were women; their age ranged between 17 and 29 years, with an average age of 20.88. No differences were found between the mean ages of men and women $(p=.765, M=20.82, S D=2.01$ for the men; $M=21.05, S D=2.33$ for the women). The data were collected by means of a questionnaire given to groups of 25 to 60 students during classes, in each of the selected university schools and faculties. Student participation was voluntary and the questionnaires were anonymous.

\section{Measures}

\section{Relationships Questionnaire (RQ)}

The RQ measures adult attachment styles through the presentation of four short paragraphs, each of which describes a typical attachment model applied to close personal relationships in general. Two different measures were used: a discrete measure, in which the participants received the four descriptions and had to choose the one that best represented their behaviour in close relationships; and a continuous measure in which the participants evaluated their degree of agreement with each one of the four descriptions on a seven-point scale (from $1=$ totally disagree to $7=$ totally agree). Following Bartholomew and Shaver's procedures (1998; see also Griffin \& Bartholomew, 1994), two attachment dimensions were then computed from the continuous singleitem scales of the paragraph measure. These dimensions reflect self and other working models that underlie the four prototypical attachment styles. The underlying attachment dimensions can be derived from linear combinations of the prototype ratings obtained from the RQ (or the composite attachment measure). The model of self (anxiety) dimension was constructed as follows: [(secure + dismissing $)-($ fearful + preoccupied $)]$, in which high scores reflect high levels of attachment anxiety and a lack of confidence. The model of the other (avoidance) dimension was constructed as follows: [(secure + preoccupied $)-($ dismissing + fearful)], in which high scores reflect high levels of attachment avoidance and discomfort with closeness. Individuals who are low in anxiety and in avoidance fall into the secure quadrant (positive models of self and positive models of others). Those who are high in anxiety and low in avoidance form the preoccupied quadrant (negative models of self and positive models of others). Individuals low in anxiety and high in avoidance fall into the dismissing category (positive models of self and negative models of others). Those high in both avoidance and anxiety form the fearful quadrant (negative models of self and others).

The RQ has shown converging validity with other adult attachment measures, such as the three-group measure of Hazan and Shaver (1987) and the Relationship Styles Questionnaire (RSQ; Griffin \& Bartholomew, 1994).

\section{Questionnaire on the history of close relationships}

The participants indicated the relationship's type or status (frequently dating; in a couple or similar relationship) and the history of past close relationships (number of relationships in the past three years).

Attitude to the disclosure of personal information within the relationship. In order to assess the participants' attitude to the disclosure of personal information, the following item was included in 
the questionnaire: What is your attitude towards verbally expressing your feelings for your partner to that person (for example, saying "I love you"), using a seven-point Likert-type scale, from -3 (totally against) to +3 (totally in favour). To assess the validity of the measure of attitude, we compared the scores given by the participants in this scale with the response they gave to the following question three weeks later: How often have you expressed your feelings to your partner (for example, said "I love you"), over the past three weeks? The obtained correlation was .56 $(p<.001)$.

\section{RESULTS}

\section{Preliminary analyses}

A series of preliminary analyses were carried out in order to obtain the distribution of the attachment styles in our study sample, as well as to verify whether relations between gender and the dependent variables in the study, on one hand, were established that were similar to those found in previous studies, and between the attachment style and such variables, on the other.

\section{Distribution of adult attachment styles}

An analysis of the frequencies of self-reported attachment styles was conducted using the categorical measure of the Bartholomew classification system. The distribution is shown on Table 1. Chi-square analyses were conducted to examine the relationship between gender and attachment style. The results indicated that there were no gender differences in attachment style $\left(\chi^{2}=.454\right.$; $d f=3 ; p<.929)$.

In order to verify whether there were any differences in the two dependent variables according to gender, attachment style and the genderattachment interaction, a MANOVA was carried

TABLE 1

Distribution of the sample by gender, according to attachment style

\begin{tabular}{lrrrrrrrr}
\hline & \multicolumn{2}{c}{ Men } & & \multicolumn{2}{c}{ Women } & & \multicolumn{2}{c}{ Total } \\
\cline { 2 - 3 } \cline { 8 - 9 } Attachment style & $n$ & $\%$ & & $n$ & $\%$ & & $N$ & $\%$ \\
\hline Secure & 117 & $58.2 \%$ & 326 & $59.8 \%$ & 443 & $59.4 \%$ \\
Dismissing & 28 & $13.9 \%$ & 69 & $12.7 \%$ & 97 & $13.0 \%$ \\
Preoccupied & 37 & $18.4 \%$ & 104 & $19.1 \%$ & 141 & $18.9 \%$ \\
Fearful & 19 & $9.5 \%$ & 46 & $8.4 \%$ & 65 & $8.7 \%$ \\
Total & 201 & & 545 & & 746 & \\
\hline
\end{tabular}

out, which showed significant main effects of gender, $F(2,741)=11.34, \eta^{2}=.030, p<.001$, and of attachment style, $F(6,1484)=12.20, \eta^{2}=.047$, $p<.001$, and a significant interaction effect of attachment by gender, $F(6,1484)=2.87, \eta^{2}=.012$, $p<.009$. Two ANOVAs were subsequently carried out, one for each dependent variable, with the latter followed by post-hoc comparisons (Tukey's HSD tests).

Differences between the genders in their attitudes to expressing feelings to their partner and in the number of past relationships. The results of the ANOVA revealed significant differences according to gender, both in the attitude to self-disclosure $\left(p<.01 ; \eta^{2}=.014\right)$ and in the number of partner relationships $\left(p<.001 ; \eta^{2}=.019\right)$. So, women reported more positive attitudes to expressing their feelings to their partner than men, and they reported a significantly lower number of past relationships than men (see Table 2).

Differences according to the adult attachment style in attitudes to communication with one's partner and in the number of past relationships. Likewise, the ANOVA revealed significant main effects for the adult attachment style ( $p<.001 ; \eta^{2}=.082$ for expressing feeling; $p<.01$; $\eta^{2}=.021$ for number of past relationships). As expected, the post-hoc comparisons indicated that secure $(M=2.54, S D=1.08)$ and preoccupied $(M=2.36, S D=1.11)$ individuals reported the most positive attitudes to expressing their feelings to their partner, while the two avoidant styles ( $M=1.81, S D=1.53$ for dismissing; $M=1.35$, $S D=1.77$ for fearful) reported the most negative attitudes (all $p$ values $<.001$ ). As for the number of partners that they had over the previous three years, the Tukey tests revealed that the participants with a fearful attachment style $(M=2.43$, $S D=2.25$ ) reported a higher number of past relationships than the participants with secure $(M=1.76, \quad S D=1.24)$, preoccupied $(M=1.82$, $S D=1.49)$, and dismissing $(M=2.24, S D=2.33)$

\section{TABLE 2}

Descriptive statistics for dependent variables for women and men

\begin{tabular}{llllr}
\hline Source & & Mean & SD & \multicolumn{1}{c}{ Range } \\
\hline Expressing feelings & Men & 2.00 & 1.528 & -3 to +3 \\
& Women & 2.42 & 1.155 & -3 to +3 \\
Number of past & Men & 2.33 & 2.077 & $1-21$ \\
relationships & Women & 1.73 & 1.327 & $1-15$ \\
\hline
\end{tabular}

$N=545$ women, 201 men. 
attachment styles. The comparisons were significant both in the case of the secure individuals compared with both groups of avoidant attachment $(p<.01$ in the case of the fearful attachment style; $p<.03$ in the case of the dismissing attachment style) and in the case of the preoccupied individuals compared with the fearful individuals $(p<.05)$.

\section{Attachment style, gender, and romantic relationships}

In order to verify $\mathrm{H} 1.1$ and $\mathrm{H} 2.1$, planned comparisons were carried out. For H1.2, H1.3, $\mathrm{H} 2.2$, and H2.3, ANOVAs were carried out, followed by Tukey's multiple comparison tests. When gender, attachment style and gender-attachment interaction were compared in the measured variables, the results revealed a significant interaction between gender and attachment $(p<.02$; $\eta^{2}=.013$ for expressing feeling; $p<.02 ; \eta^{2}=.013$ for number of past relationships).

\section{Hypothesis 1: Number of past relationships}

H1.1 predicted that men with the dismissing attachment style would report a higher number of past relationships than secure and preoccupied men. This hypothesis was tested with a planned comparison, in which contrast coefficients were set at 2 for dismissing, at -1 for secures, at -1 for preoccupieds, and at 0 for fearful avoidants. A significant contrast was observed, $F(1,738)=$ $11.566, p<.001$, effect size $(r)=.124$. As we expected, men with the dismissing attachment style had maintained more relationships in the past $(M=3.29, S D=3.75)$ than secure $(M=2.13$, $S D=1.58)$ and preoccupied $(M=2.22, S D=$ 1.49) men.

H1.2 predicted that women with the dismissing attachment style would not significantly differ from all the other women with other styles in the number of partner relationships. As expected, the post-hoc comparisons (Tukey's HSD tests) indicated that dismissing women $(M=1.81$, $S D=1.22)$ did not significantly differ from secure $\quad(M=1.63, \quad S D=1.06), \quad$ preoccupied $(M=1.68, \quad S D=1.47), \quad$ or fearful $(M=2.46$, $S D=2.33$ ) women. Lastly, we only expected to find differences between men and women in the number of past relationships in the case of the dismissing attachment group (H1.3). The results of the post-hoc comparisons, in line with H1.3, revealed that there were only significant differences between dismissing men and women $(p<.001)$.

\section{Hypothesis 2: Attitudes to expressing feelings to one's partner}

$\mathrm{H} 2.1$ predicted that men with dismissing attachment style would report more negative attitudes to the disclosure of personal information than secure and preoccupied men. This hypothesis was tested with a planned comparison, in which contrast coefficients were set at 2 for dismissing, at -1 for secures and preoccupieds, and at 0 for fearful. A significant contrast was observed, $F(1,738)=23.611, p<.001$, effect size $(r)=.176$. As expected, dismissing men reported the most negative attitudes to expressing their feelings to their partner $(M=1.07, S D=1.88)$, compared with secure $(M=2.25, S D=1.33)$ and preoccupied $(M=2.38, S D=1.21)$ men.

H.2.2 predicted that women with the dismissing attachment style would not significantly differ from all the women with other styles in their attitudes to the disclosure of personal information. The results of the post hoc comparisons partially supported our hypotheses, given that, as expected, dismissing women $(M=2.12, S D=1.25) \quad$ did not significantly differ from preoccupied women $(M=2.36, S D=1.08)$ or fearful women $(M=1.41$, $S D=1.75)$ in their attitudes to expressing their feelings to their partner. Nevertheless, secure women $(M=2.65, S D=.94)$ did significantly differ in their attitudes from dismissing women $(p<.002)$.

Lastly, we expected the only differences between men and women as regards attitudes to be found in the case of the dismissing attachment group (H.2.3). As expected, the post-hoc comparisons indicated that significant differences in the comparisons between men and women with the same attachment style were only found in the case of the dismissing style $(p<.001)$.

\section{DIsCUSSION}

This study was carried out in order to investigate the possible gender-attachment interactions in the context of romantic relationships and particularly on the degree of stability and intimacy in relationships.

Preliminary analyses confirmed that women are more willing than men to disclose their feelings to their partner (which would affect the degree of intimacy in the relationship) and they maintain fewer partner relationships. These findings are 
consistent with those found in other studies in different cultures (e.g. Canary \& Wahba, 2006; Hendrick \& Hendrick, 1995; Murstein \& Adler, 1995; Yela, 2000).

These differences would highlight how men and women are socialized to perceive and behave differently in their relationships (Reis, 1998). Social pressure probably leads men to inhibit their self-disclosure and their search for intimacy, and makes them feel uncomfortable expressing what they feel.

Regarding the relationship between secure and insecure attachment and intimacy and stability in romantic relationships, the results obtained in the preliminary analyses corroborate those found in many other studies, which consistently show that the attachment style acts as an important predictor of the functioning and quality of adult romantic relationships (Collins \& Read, 1990; Kirkpatrick \& Davis, 1994; Monteoliva \& García-Martínez, 2005).

So, our results revealed that, compared with the avoidant individuals (both dismissing and fearful), secure and preoccupied individuals reported the most positive attitudes to expressing their feelings to their partner and reported a lower number of break-ups in their history of past relationships. All these results appear to confirm the cognitive schema that the theory predicts for each standard.

\section{Effects of the interaction between gender and adult attachment style}

The hypotheses in our study were aimed at verifying whether gender played a moderating role in the relationship between attachment style and stability and intimacy in romantic relationships. We specifically expected to find a significant effect of the gender-attachment interaction in the case of the dismissing attachment style - results that have been confirmed in this study. In keeping with other studies (Birnbaum et al., 2006; Feeney, 1999b; Kirkpatrick \& Davis, 1994), these results suggest that attachment style and gender role socialization have a joint influence on different aspects of romantic relationships.

So, both in the case of the number of past partner relationships and in the case of attitudes to disclosing feelings to one's partner, significant differences were found between secure and preoccupied men, compared with dismissing men, whereby the latter reported the highest number of relationships and the most negative attitudes. However, in the case of women, the dismissing group did not differ from the rest of the women with other attachment styles (both secure and insecure) in any of the analyzed variables. Differences were only found in the case of attitudes to disclosing feelings to one's partner between women with dismissing and secure styles, where the latter reported the most positive attitudes. Furthermore, when men and women with the same attachment styles were compared in both variables, the results showed that, in the case of the number of partner relationships, the only significant differences were found between dismissing and secure men and women (with the latter reporting fewer partners), while, in the case of the attitudes to disclosing feelings, men and women did not differ in three of the four attachment groups, but they did differ in the dismissing attachment group, where women showed the most positive attitudes.

All these results could be explained from the viewpoint of a traditionally feminine gender role socialization, seeing that, as Scott and Cordova (2002) have proposed, this role encourages women to feel a greater sense of responsibility for and to make greater efforts to maintain relationships than men. Moreover, compared with the traditional male gender role, the female sex nurtures the desire for emotional closeness and the expression of feelings (Surra \& Longstreth, 1990).

The results obtained in this study are in line with those of other authors. So, for example, Shaver and Hazan (1993) consider preoccupied women and avoidant men to be better examples of cultural stereotypes than men and women in the other attachment groups. Simpson, Rholes, and Phillips (1996) suggest that the gender role socialization could predominate over the prototypical attitudes and behaviour of each attachment style, particularly in the case of the avoidant group.

The fact that dismissing women report fewer past partner relationships and more positive attitudes to self-disclosure than dismissing men, and that they do not differ from women with other styles (contrary to what was expected according to their attachment style), would reveal that they behave more in line with their gender role socialization than what would be typical of their attachment style, seeing as dismissing men, on the other hand, do report attitudes and behaviour in line with both their gender role and their attachment style. Being a man and being dismissing (the style more consistent with their traditional gender role) enables the influence of both factors to make their attitudes and behaviour in their relationships more marked, as the results appear to indicate. As Feeney (1999b) points out, the dismissing attachment style could exaggerate the 
gender role stereotype of men. In dismissing women, on the other hand, the effect of attachment style appears to be cancelled out by the influence of gender role socialization, even in the case of expressing feelings to one's partner, a behaviour that has not been as socially disapproved of as that of maintaining a higher or lower number of partner relationships.

These results could be interpreted from the sexual double standard concept, which refers to the different ways in which men and women are socialized in the field of intimate and sexual relationships, such that men have more sexual freedom (premarital sex, multiple sexual partners, first sexual encounter at an earlier age), whereas women are the object of social sanctions or censorship for the same behaviour (Crawford \& Popp, 2003). Despite the advances made in achieving equality, this phenomenon still appears to be very much in operation, as the results of several studies show (Crawford \& Popp, 2003; Kreager \& Staff, 2009). These studies have revealed that, while women who have had a high number of sexual partners are stigmatized and unpopular, the same is not the case for men, who are rewarded with popularity and admiration. In Spain, some studies that have dealt with double standards in a university population reveal that this phenomenon still exists, and more restrictive sexual attitudes are upheld for women than for men (Diéguez, Sueiro, \& López, 2003). Moreover, even though hostile sexism is more frequent among men, a significant percentage of women also express this type of attitude (Sierra, Gutiérrez, Rojas, \& Ortega, 2007). Nevertheless, it is worth pointing out that, given that more recent studies have shown evidence that contradicts the idea that violating the sexual double standard is associated with a greater social sanction (e.g., Lyons, Giordano, Manning, \& Longmore, 2010), some authors suggest that this phenomenon may be changing and becoming more complex (Marks \& Fraley, 2006; Milhausen \& Herold, 2001).

Our results could also be discussed from evolutionary perspectives in which romantic attachment is associated with basic human mating strategies. Some authors have proposed that the attachment styles could be a reflection of different reproductive strategies (short-term strategy/long-term strategy), making secure and preoccupied styles correspond to a long-term strategy and the avoidant styles correspond to a short-term strategy (Del Giudice, 2009; Kirkpatrick, 1998). The link between avoidant attachment and long-term strategy has been extensively supported by research in this field, given the results consistently found in people with a dismissing attachment style, who show greater frequency of sporadic sexual relationships with no commitment, and a higher level of promiscuity, or a greater break-up rate. It is worth pointing out, however, that these results have been found in the case of dismissing men, but not in the case of dismissing women (for a review, see Allen \& Baucom, 2004), which would support the hypothesis put forward by Del Giudice (2009) in his evolutionary model, which proposes that this short-term human matching strategy is adaptive particularly in the case of dismissing men, but not in the case of dismissing women.

\section{Limitations and directions for future research}

Before concluding, we should acknowledge one of this study's limitations. Gender and not gender role has been used, in spite of the fact that the results obtained in some studies (see SteinerPappalardo \& Gurung, 2002) suggest that a gender role measure may be more predictive of the quality in partner relationships than gender. We believe that future studies would need to verify whether gender role also has a moderating effect among the variables that have been analyzed here. Second, the interpretation of the present data should be cautious because we only examined the Spanish population. The possible cultural differences of the gender-attachment interactions in the context of intimate relationships may be a topic for future research, in which other variables related to the functioning and quality of romantic relationships (variables that have not been studied here) could also be analyzed.

\section{CONCLUSION}

In spite of these limitations, this study illustrates the separate and joint effects of gender and attachment styles on intimacy and the degree of stability in relationships. On one hand, the results of this study repeat those found in existing studies about attachment and about gender in intimate relationships, independently, but on the other hand, they reveal that attachment interacts with gender, giving rise to different results in romantic behaviour and attitudes: Dismissing men and women show different attitudes to communication and a different degree of stability in their partner relationships. The study contributes to a greater understanding of the complex relationships 
between attachment, gender, and intimate relationships, reflecting how gender has a moderating effect on the relationship between attachment and partner relationships. Studying gender and attachment together seems to offer a more complete vision of the nature of the intimate processes than doing so separately.

Manuscript received September 2010 Revised manuscript accepted June 2011

First published online January 2012

\section{REFERENCES}

Allen, E. S., \& Baucom, D. H. (2004). Adult attachment and patterns of extradyadic involvement. Family Process, 43, 467-488.

Bartholomew, K. (1990). Avoidance of intimacy: An attachment perspective. Journal of Social and Personal Relationships, 7, 147-178.

Bartholomew, K., \& Horowitz, L. M. (1991). Attachment styles among young adults: A test of a four-category model. Journal of Personality and Social Psychology, 61, 226-244.

Bartholomew, K., \& Shaver, P. (1998). Measures of attachment: Do they converge? In J. A. Simpson \& W. S. Rholes (Eds.), Attachment theory and close relationships (pp. 25-45). New York, NY: Guilford Press.

Birnbaum, G. E., Reis, H. T., Mikulincer, M., Gillath, O., \& Orpaz, A. (2006). When sex is more than just sex: Attachment orientations, sexual experience, and relationship quality. Journal of Personality and Social Psychology, 91, 929-943.

Bowlby, J. (1969/1982). Attachment and loss (Vol. 1). New York, NY: Basic Books.

Canary, D. J., \& Wahba, J. (2006). Do women work harder than men at maintaining relationships? In K. Dindia \& D. J. Canary (Eds.), Sex differences and similarities in communication (2nd ed., pp. 359-377). Mahwah, NJ: Lawrence Erlbaum Associates.

Collins, N. L., \& Read, S. J. (1990). Adult attachment, working models and relationship quality in dating couples. Journal of Personality and Social Psychology, $58,644-663$.

Crawford, M., \& Popp, D. (2003). Sexual double standards: A review and methodological critique of two decades of research. Journal of Sex Research, 40, 13-26.

Del Giudice, M. (2009). Sex, attachment, and the development of reproductive strategies. Behavioral and Brain Sciences, 32, 1-67.

Diéguez, K. L., Sueiro, E., \& López, F. (2003). The sexual double standard y variables relacionadas. Cuadernos de Medicina Psicosomática y Psiquiatría de Enlace, 67/68, 79-88.

Eagly, A. (1987). Sex differences in social behavior: A social-role interpretation. Hillsdale, NJ: Lawrence Erlbaum Associates.

Feeney, J. A. (1999a). Adult romantic attachment and couple relationships. In J. Cassidy \& P. R. Shaver (Eds.), Handbook of attachment: Theory, research, and clinical applications (pp. 355-377). New York, NY: Guilford Press.
Feeney, J. A. (1999b). Issues of closeness and distance in dating relationships: Effects of sex and attachment style. Journal of Social and Personal Relationships, 16, 571-590.

Griffin, D. W., \& Bartholomew, K. (1994). Models of the self and other: Fundamental dimensions underlying measures of adult attachment. Journal of Personality and Social Psychology, 67, 430-445.

Hazan, C., \& Shaver, P. R. (1987). Romantic love conceptualized as an attachment process. Journal of Personality and Social Psychology, 52, 511-524.

Hendrick, S. S., \& Hendrick, C. (1995). Gender differences and similarities in sex and love attitudes. Personal Relationships, 2, 55-65.

Instituto de la Juventud (2004). Parejas y formas de convivencia de la juventud [Partners and young people's ways of living together]. Revista de Estudios de Juventud, 67.

Kirkpatrick, L. A. (1998). Evolution, pair bonding, and reproductive strategies: A reconceptualization of adult attachment. In J. A. Simpson \& W. S. Rholes (Eds.), Attachment theory and close relationships (pp. 353-393). New York, NY: Guilford Press.

Kirkpatrick, L. A., \& Davis, K. E. (1994). Attachment style, gender and relationship stability: A longitudinal analysis. Journal of Personality and Social Psychology, 66, 502-512.

Kreager, D., \& Staff, J. (2009). The sexual double standard and adolescent peer acceptance. Social Psychology Quarterly, 72, 143-164.

Lyons, H., Giordano, P. C., Manning, W. D., \& Longmore, M. A. (2010). Identity, peer relationships, and adolescent girls' sexual behavior: An exploration of the contemporary double standard. Journal of Sex Research, 47, 1-13.

Marks, M., \& Fraley, R. C. (2006). Confirmation bias and the sexual double standard. Sex Roles, 54, 19-26.

Mikulincer, M., \& Shaver, P. R. (2007). Attachment in adulthood: Structure, dynamics, and change. New York, NY: Guilford Press.

Milhausen, R., \& Herold, E. (2001). Reconceptualizing the sexual double standard. Journal of Psychology and Human Sexuality, 13, 63-83.

Monteoliva, A., \& García-Martínez, J. M. A. (2005). Adult attachment style and its effects on the quality of romantic relationships in Spanish students. Journal of Social Psychology, 145, 745-747.

Murstein, B. I., \& Adler, E. R. (1995). Gender differences in power and self-disclosure in dating and married couples. Personal Relationships, 2, 199-209.

Perlman, D., \& Fehr, B. (1987). The development of intimate relationships. In D. Perlman \& S. Duck (Eds.), Intimate relationships: Development, dynamics, and deterioration (pp. 13-42). Thousand Oaks, CA: Sage.

Pietromonaco, P. R., \& Carnelley, K. B. (1994). Gender and working models of attachment: consequences for perceptions of self and romantic relationships. Personal Relationships, 1, 63-82.

Pistole, M. C. (1993). Attachment relationships: Selfdisclosure and trust. Journal of Mental Health Counseling, 15, 94-106.

Powers, S., Pietromonaco, P. R., Gunlicks, M., \& Sayer, A. (2006). Dating couples' attachment styles and patterns of cortisol reactivity and recovery in 
response to a relationship conflict. Journal of Personality and Social Psychology, 90, 613-628.

Reis, H. T. (1998). Gender differences in intimacy and related behaviors: Context and process. In D. J. Canary \& K. Dindia (Eds.), Sex differences and similarities in communication (pp. 203-231). Mahwah, NJ: Lawrence Erlbaum Associates.

Reis, H. T., \& Patrick, B. C. (1996). Attachment and intimacy: Component processes. In E. T. Higgins \& A. W. Kruglanski (Eds.), Social psychology: Handbook of basic principles (pp. 523-563). New York, NY: Guilford Press.

Schmitt, D. P., Alcalay, L., Allensworth, M., Allik, J., Ault, L., Austers, I., et al. (2003). Are men universally more dismissing than women? Gender differences in romantic attachment across 62 cultural regions. Personal Relationships, 10, 307-331.

Scott, R. L., \& Cordova, J. V. (2002). The influence of adult attachment styles on the association between marital adjustment and depressive symptoms. Journal of Family Psychology, 16, 199-208.

Shaver, P. R., \& Hazan, C. (1993). Adult romantic attachment: Theory and evidence. In D. Perlman \& W. Jones (Eds.), Advances in Personal Relationships (pp. 29-70). London, UK: Jessica Kingsley.

Sierra, J. C., Gutiérrez, R., Rojas, A., \& Ortega, V. (2007). Estudio transcultural sobre prejuicios sexuales (doble moral sexual y actitud favorable hacia la violación) entre estudiantes universitarios españoles y salvadoreños. Paper presentada at the $31 \mathrm{st}$ Congreso Interamericano de Psicología, Mexico City, Mexico.

Simpson, J. A., Collins, W. A., Tran, S., \& Haydon, K. C. (2007). Attachment and the experience and expression of emotions in romantic relationships: A developmental perspective. Journal of Personality and Social Psychology, 92, 355-367.

Simpson, J. A., Rholes, W. S., \& Phillips, D. (1996). Conflict in close relationships: An attachment perspective. Journal of Personality and Social Psychology, 71, 899-914.

Steiner-Pappalardo, N. L., \& Gurung, R. A. (2002). The femininity effect: Relationship quality, sex, gender, attachment, and significant-other concepts. Personal Relationships, 9, 313-325.

Surra, C. A., \& Longstreth, M. (1990). Similarity of outcomes, interdependence, and conflict in dating relationships. Journal of Personality and Social Psychology, 59, 501-516.

Teva, I., Bermúdez, M. P., \& Buela-Casal, G. (2009). Characteristics of sexual behavior in Spanish adolescents. Spanish Journal of Psychology, 2, 471-484.

van IJzendoorn, M. H., \& Sagi, A. (1999). Crosscultural patterns of attachment. In J. Cassidy \& P. R. Shaver (Eds.), Handbook of attachment: Theory, research and clinical applications (pp. 713-734). New York, NY: Guilford Press.

Wood, W., \& Eagly, A. H. (2002). A cross-cultural analysis of the behavior of women and men: Implications for the origins of sex differences. Psychological Bulletin, 128, 699-727.

Yárnoz, S., Alonso-Arbiol, I., Plazaola, M., \& Sanz de Murieta, L. M. (2001). Apego en adultos y percepción de los otros [Attachment in adults and perception of others]. Anales de Psicologia, 17, 159-170.

Yela, C. (2000). Predictors of and factors related to loving and sexual satisfaction for men and women. European Review of Applied Psychology, 50, 235-243. 